\title{
ARTIKELEN
}

\section{Bereidheid om samen te werken met actoren in de strafrechtketen: de invloed van procedurele rechtvaardigheid in Nederland}

\author{
Matthias van Hall
}

Criminologisch onderzoek benadrukt het belang van procedurele rechtvaardigheid van autoriteiten tijdens hun ontmoetingen met burgers. Theorie en eerder onderzoek veronderstellen dat de procedureel rechtvaardige bejegening door de politie, al dan niet via legitimiteit, van invloed is op de bereidheid van burgers om samen te werken met actoren in de strafrechtketen. Dit artikel toetst de hypothesen van de procedurele rechtvaardigheidstheorie met Nederlandse gegevens van de European Social Survey $(N=1.616)$. De resultaten tonen een verband tussen de procedureel rechtvaardige bejegening van burgers door de politie en de bereidheid tot samenwerking met strafrechtactoren. Dit verband wordt echter niet verklaard door legitimiteitsovertuigingen over de politie.

\section{Introductie}

Om effectief te werken en criminaliteit te bestrijden, heeft de politie voortdurende steun en vrijwillige medewerking van burgers nodig (Murphy e.a., 2008; Skogan \& Frydl, 2004; Tyler \& Fagan, 2008). Zo kunnen burgers de politie helpen door aangifte te doen van strafbare feiten of helpen bij het opsporen van gezochte verdachten van een strafbaar feit. De bereidheid van burgers om samen te werken met actoren in de strafrechtketen, zoals de politie, is veelal onderzocht door, bijvoorbeeld, burgers te vragen naar de mate waarin ze genegen zijn om de politie te bellen bij het waarnemen van een strafbaar feit (Bolger \& Walters, 2019; Jackson e.a., 2011a). Mede door de hulp van burgers kan de politie een onderzoek instellen en mogelijk effectiever (en efficiënter) werken aan het opsporen van verdachten en strafbare feiten (Van Os e.a., 2007; Tyler, 2009). De samenwerking met strafrechtactoren betreft overigens niet uitsluitend criminaliteitsbestrijding, maar een breder palet aan taken, zoals het handhaven van de openbare orde (en mogelijk de hulpverlening aan burgers dan wel slachtoffers). Het vinden van manieren om burgers aan te moedigen om samen te werken met de politie en andere wetshandhavers is daarom van cruciaal belang.

Een theorie die aanknopingspunten oplevert over factoren die de bereidheid tot samenwerking met strafrechtactoren kunnen bevorderen, is de procedurele rechtvaardigheidstheorie. Deze theorie veronderstelt dat wanneer mensen zich respectvol bejegend voelen door autoriteiten en de besluitvormingsprocedures als eerlijk ervaren (kortweg een 'procedureel rechtvaardige bejegening'), ze de betref- 
fende autoriteiten eerder als legitiem zullen beschouwen en sneller geneigd zullen zijn om met hen samen te werken (Tyler, 2003; 2006). Vertaald naar de strafrechtketen betekent dit dat wanneer men zich procedureel rechtvaardig bejegend voelt door strafrechtactoren, zoals de politie of de rechter, men ook eerder bereid zal zijn om hen te helpen en met hen samen te werken. Tal van empirische studies ondersteunen de hypothesen van de procedurele rechtvaardigheidstheorie: de procedureel rechtvaardige bejegening door actoren in de strafrechtketen hangt samen met opvattingen over de legitimiteit van deze actoren, die vervolgens de bereidheid om samen te werken met actoren beïnvloeden (Bolger \& Walters, 2019; Murphy e.a., 2008; Reisig e.a., 2007; Sunshine \& Tyler, 2003; Tyler \& Fagan, 2008).

Hoewel de procedurele rechtvaardigheidstheorie eerder voornamelijk in Australië, het Verenigd Koninkrijk en de Verenigde Staten is getoetst, zijn de veronderstellingen van deze theorie in toenemende mate in andere contexten onderzocht. Er is eerder namelijk de kritiek geuit dat Angelsaksische landen wezenlijke verschillen vertonen met andere landen ten aanzien van het (straf)recht en het strafrechtsysteem en dat het maar de vraag is in hoeverre de eerdere onderzoeksbevindingen te generaliseren zijn naar andere landen (Hough e.a., 2010; Tankebe, 2009). Studies buiten de voornoemde Angelsaksische landen laten dan ook meer uiteenlopende bevindingen zien met betrekking tot de effecten van een rechtvaardige bejegening (Reisig \& Lloyd, 2009; Reisig e.a., 2012; Tankebe, 2009; Van Damme \& Pauwels, 2013; Van Damme e.a., 2015).

In 2010 is er in Europa, waaronder in Nederland, een grootschalig kwantitatief onderzoek - de European Social Survey - uitgevoerd naar de procedurele rechtvaardigheidstheorie. Hieruit is gebleken dat Nederlanders, in vergelijking met burgers in andere Europese landen, gemiddeld genomen een gemiddelde tot hoge score hebben met betrekking tot procedurele rechtvaardigheid en legitimiteitsovertuigingen (Jackson e.a., 2011a), terwijl het vertrouwen in de politie relatief hoog is (Schaap \& Scheepers, 2014). Mede op basis van deze gegevens, en gegevens van de Veiligheidsmonitor, zijn er in Nederland voornamelijk studies uitgevoerd naar het vertrouwen in de politie onder burgers, jongeren met een migratieachtergrond en slachtoffers van criminaliteit (Broekhuizen e.a., 2018; 2015; Van Dijk, 2007; Koster, 2018; Regioplan, 2005; Schaap, 2014; 2018; Terpstra, 2008; Van der Veer e.a., 2013). Enkele studies benadrukken het belang om de determinanten van de samenwerking met (en het vertrouwen in) de politie nader te onderzoeken (Broekhuizen e.a., 2015; Schaap, 2018). Recent heeft Koster (2018) de samenhang tussen de bejegening door de politie en de samenwerking met de politie onderzocht onder slachtoffers van criminaliteit. Opvallend is echter dat het verband tussen procedurele rechtvaardigheid en de samenwerking met strafrechtactoren nog niet eerder is getoetst onder een representatieve steekproef van burgers in Nederland.

De huidige studie richt zich daarom op de procedurele rechtvaardigheid en de bereidheid om met strafrechtactoren samen te werken. De onderzoeksvraag luidt als volgt: in welke mate heeft een procedureel rechtvaardige bejegening door de politie, al dan niet via legitimiteit, invloed op de bereidheid tot samenwerking met actoren in de strafrechtketen in Nederland? Om deze vraag te beantwoorden 
worden cross-sectionele onderzoeksgegevens gebruikt uit een steekproef van de European Social Survey (ronde 5, jaar 2010) bestaande uit 1.616 Nederlanders.

\section{Theorie en eerder onderzoek}

\section{De bereidheid tot samenwerking: de werking van procedurele rechtvaardigheid}

Wetenschappers uit allerlei vakgebieden, zoals de criminologie, de (sociale) psychologie en de sociologie, hebben factoren onderzocht die de bereidheid van mensen om samen te werken met strafrechtactoren, zoals de politie, (kunnen) verklaren. Een van de verklaringen voor coöperatief gedrag is gebaseerd op rationele keuzes over kosten en baten (Nagin, 1998; Tyler \& Fagan, 2008). Dit uitgangspunt veronderstelt dat acties van mensen voornamelijk worden beïnvloed door hun eigenbelang. In overeenstemming met deze rationele-keuzebenadering kan de politie de samenwerking bevorderen door bijvoorbeeld aan te tonen dat ze effectief is in het bestrijden van criminaliteit, of dat overtreders worden bestraft. Zo is, bijvoorbeeld, eerder gebleken dat buurtbewoners gemotiveerd worden om met elkaar samen te werken en criminaliteit te bestrijden wanneer zij de opvatting hebben dat de gemeenschap collectief en effectief werkt om lokale problemen aan te pakken (Sampson \& Bartusch, 1998; Sampson e.a., 1997). Echter, vanuit deze instrumentele benadering is het soms in het eigen belang van burgers om niet samen te werken met de politie (Tyler, 2006). Dat wil zeggen dat sommige mensen weinig direct persoonlijk nut zien in het ondersteunen van de politie om criminaliteit te beperken, om strafbare feiten te melden of om de gemeenschap te helpen criminaliteit te bestrijden. Bovendien kan het samenwerken met actoren in de strafrechtketen op korte termijn kosten opleveren. Die kosten kunnen kleine ongemakken zijn, maar ook een ernstig gevaar voor vergelding inhouden. Kortom, strategieën die enkel een beroep doen op eigenbelang zijn vaak een onvoldoende basis om samen te werken met strafrechtactoren of om de wet te gehoorzamen (MacCoun, 1993; Sunshine \& Tyler, 2003). Een andere invalshoek is de procedurele rechtvaardigheidstheorie. Deze theorie veronderstelt dat mensen eerder geneigd zijn om met actoren in de strafrechtketen samen te werken wanneer zij zich door hen procedureel rechtvaardig bejegend voelen (Sunshine \& Tyler, 2003; Tyler, 2001; 2006). Volgens deze theorie vinden mensen de eerlijkheid in de besluitvorming en het respect in de bejegening belangrijker dan de uitkomsten van beslissingen door autoriteiten (Thibaut \& Walker, 1975). Een bejegening is procedureel rechtvaardig wanneer mensen de mogelijkheid hebben om deel te nemen in het proces door hun stem te laten horen, het besluitvormingsproces neutraal is, regels consistent worden toegepast, autoriteiten uit betrouwbare motieven handelen, en men op een respectvolle en waardige manier bejegend wordt (Goodman-Delahunty, 2010; Tyler, 2003; Tyler \& Murphy, 2011).

Door de uitoefening van gezag op een eerlijke, neutrale en consistente manier, waarbij autoriteiten mensen op een respectvolle manier bejegenen, worden de banden tussen individuen en autoriteiten versterkt. Procedurele rechtvaardigheid van autoriteiten tijdens hun ontmoetingen met mensen versterkt de identificatie 
van deze mensen met de groep die de autoriteit vertegenwoordigt, met als gevolg dat mensen de regels van die groep gaan internaliseren en gehoorzamen (Blader \& Tyler, 2009; Jackson e.a., 2015; Sunshine \& Tyler, 2003; Tyler \& Jackson, 2014). In andere woorden, een procedureel rechtvaardige bejegening door autoriteiten maakt mensen duidelijk dat ze onderdeel van de groep zijn en gewaardeerd worden. Een procedureel onrechtvaardige bejegening toont daarentegen een gebrek aan respect, wat ertoe kan leiden dat mensen zich uitgesloten voelen van de groep en weerstand opbouwen tegen de vertegenwoordigende autoriteiten van de groep. Toegepast op de context van de strafrechtketen betekent dit dat een procedureel rechtvaardige bejegening door strafrechtactoren, zoals de politie, zal resulteren in een hogere bereidheid om met strafrechtactoren samen te werken, omdat burgers zich door de procedureel rechtvaardige bejegening onderdeel zijn gaan voelen van de groep.

Over het algemeen lijkt empirisch onderzoek de procedurele rechtvaardigheidstheorie te ondersteunen. Bestaande studies onder burgers hebben aangetoond dat percepties van procedurele rechtvaardigheid de tevredenheid met autoriteiten (Reisig \& Chandek, 2001; Tyler \& Huo, 2002) en de bereidheid om beslissingen van autoriteiten te accepteren, verhogen (Tyler \& Huo, 2002; Tyler \& Wakslak, 2004). Daarnaast wordt ondersteuning gevonden voor een samenhang tussen percepties van procedurele rechtvaardigheid en voorgenomen (toekomstig) gedrag van burgers. Onderzoek heeft bijvoorbeeld bevestigd dat burgers die zich eerlijker en respectvoller bejegend voelen door autoriteiten, zoals de politie, eerder bereid zijn om te participeren in de preventie van criminaliteit (Reisig, 2007), of om samen te werken met de politie (Kochel, 2018; Radburn e.a., 2018; Reisig \& Lloyd, 2009; Sun e.a., 2017).

\section{De veronderstelde rol van legitimiteit in de relatie tussen procedurele rechtvaardigheid en de bereidheid tot samenwerking}

Volgens de procedurele rechtvaardigheidstheorie van Tyler (2003; 2006) hebben percepties van procedurele rechtvaardigheid direct en indirect invloed op het al dan niet willen samenwerken met strafrechtactoren. De indirecte invloed van procedurele rechtvaardigheid op de samenwerking loopt via legitimiteit. Met legitimiteit wordt bedoeld dat burgers een autoriteit erkennen, dat ze de overtuiging hebben dat autoriteiten het recht hebben om gepast gedrag te bepalen of te vereisen, en dat ze vanwege deze overtuiging bereid zijn om vrijwillig de aanwijzingen of wetten van autoriteiten na te leven (Tyler, 2003). De procedurele rechtvaardigheidstheorie veronderstelt dus dat burgers vrijwillig de wet zullen gehoorzamen vanwege de legitimiteit van actoren in de strafrechtketen, zoals de politie, en niet vanuit angst voor eventuele sancties die volgen op ongehoorzaamheid. Jackson en collega's (2012) maken een treffend onderscheid tussen twee dimensies van legitimiteit. Volgens hen is legitimiteit (1) de erkenning van de macht door burgers die gebaseerd is op het idee dat een autoriteit legitiem is, en (2) de rechtvaardiging van de macht op grond van gedeelde normen en waarden van burgers met autoriteiten. In de context van de strafrechtketen betekent dit dat legitimiteit van strafrechtactoren tot stand komt door de bereidwilligheid van burgers om de politie te gehoorzamen (verplichting om te gehoorzamen) en door 
de overtuiging dat de politie dezelfde normen en waarden deelt met de burger (morele verbondenheid) (Jackson e.a., 2012).

De mate waarin mensen een autoriteit als legitiem beschouwen, is (gedeeltelijk) gebaseerd op de procedureel rechtvaardige bejegening door de autoriteit. Opvattingen, attitudes en houdingen van mensen ten opzichte van autoriteiten worden namelijk beïnvloed door wat mensen ervaren tijdens ontmoetingen met autoriteiten. Mensen die zich eerlijk en respectvol bejegend voelen (procedurele rechtvaardigheid) door een autoriteit zijn eerder geneigd om sociale normen en waarden te internaliseren die overeenkomen met legitimiteit (Jackson e.a., 2015; Piquero e.a., 2005; Sunshine \& Tyler, 2003; Tyler, 2006). Deze geïnternaliseerde overtuigingen bieden burgers een invloedrijk referentiepunt dat hun gedrag stuurt (Smith, 2007). Legitimiteit weerspiegelt dus een belangrijke sociale waarde, waarop autoriteiten een beroep kunnen doen om bijvoorbeeld de samenwerking te bevorderen (Tyler \& Fagan, 2008; Tyler \& Jackson, 2014).

\section{Onderzoek naar procedurele rechtvaardigheid en de samenwerking met strafrechtactoren in - en buiten - Angelsaksische landen}

Bestaand onderzoek onder burgers in Angelsaksische landen heeft de veronderstelde mediërende rol van legitimiteit in de relatie tussen procedurele rechtvaardigheid en de samenwerking met strafrechtactoren grotendeels ondersteund (Reisig e.a., 2007; Sunshine \& Tyler, 2003; Tyler \& Fagan, 2008; Tyler \& Jackson, 2014). Sunshine en Tyler (2003) hebben bijvoorbeeld getoond dat burgers die zich procedureel rechtvaardig bejegend voelden door de politie, de politie ook als legitiemer beschouwden en meer bereid waren om samen te werken met de politie. Mazerolle en collega's (2013) hebben een observationele studie uitgevoerd. In een experiment waarbij de verkeerspolitie een alcoholtest uitvoerde, maakten ze onderscheid tussen een experimentele groep waarin politieagenten de opdracht kregen om burgers rechtvaardig te bejegenen, en een controlegroep waarin politieagenten de opdracht kregen om burgers te bejegenen zoals ze dat normaal doen. Vergeleken met de controlegroep voelden burgers in de experimentele groep zich rechtvaardiger bejegend, ze beschouwden de politie als legitiemer en waren meer bereid om samen te werken met de politie. Volledigheidshalve dient hier vermeld te worden dat conclusies in andere studies, waarin eveneens gebruik is gemaakt van een experiment, niet zo positief zijn als die van Mazerolle en collega's (zie bijvoorbeeld MacQueen \& Bradford, 2015; Worden \& McLean, 2017).

De bevindingen van een meta-analyse van Bolger en Walters $(2019)^{1}$ bevestigden de toepasbaarheid van Tylers theorie op het hele strafrechtsysteem, waaronder het werk van de politie. Ze vonden dat percepties van procedurele rechtvaardigheid van invloed waren op zowel legitimiteitsovertuigingen als de samenwerking met strafrechtactoren, en dat legitimiteitsovertuigingen ook de bereidheid tot samenwerking met het strafrechtsysteem beïnvloedden. Overigens lieten de resultaten zien dat het effect van procedurele rechtvaardigheid en legitimiteit op

1 In de meta-analyse van Bolger en Walters zijn de gegevens van de European Social Survey met betrekking tot Nederland eveneens geanalyseerd. 
de bereidheid om samen te werken met strafrechtactoren ongeveer even groot was (Bolger \& Walters, 2019).

Eerder onderzoek buiten Angelsaksische landen laat een diverser beeld zien. Zo bleek bijvoorbeeld in een aantal studies - in Jamaica, Ghana en Japan - dat opvattingen over de legitimiteit van de politie niet gerelateerd waren aan de samenwerking met de politie (Reisig \& Lloyd, 2009; Tankebe, 2009; Tsushima \& Hamai, 2015). Ander onderzoek - in Turkije, Slovenië, België, Zweden en ZuidKorea - toonde dat percepties van procedurele rechtvaardigheid alleen indirect via legitimiteit van invloed waren op de samenwerking met de politie (Karakus, 2017; Reisig e.a., 2012; Van Damme \& Pauwels, 2013; Van Damme e.a., 2015; Woo e.a., 2018). Daarentegen vond een andere studie - in China - dat procedurele rechtvaardigheid zowel een direct effect als een indirect effect (via legitimiteit) had op de samenwerking met de politie (Sun e.a., 2017). Kortom, het mechanisme van de manier waarop de bereidheid om samen te werken beïnvloed werd, varieerde per studie.

\section{Nederlands onderzoek naar procedurele rechtvaardigheid en de samenwerking met strafrechtactoren}

In Nederland is er veelal onderzoek gedaan naar de procedureel rechtvaardige bejegening door de politie en het vertrouwen in de politie. Zo maakte het onderzoek van Broekhuizen en collega's (2018) duidelijk dat jongeren zich over het algemeen procedureel rechtvaardig bejegend voelen door de politie (zie ook Van Kapel e.a., 2019). Tegelijkertijd voelen jongeren met een niet-westerse migratieachtergrond zich, gemiddeld genomen, minder procedureel rechtvaardig bejegend ten opzichte van jongeren met een Nederlandse achtergrond (Van Kapel e.a., 2019). Daarnaast laat eerder onderzoek zien dat het vertrouwen van burgers in de politie, in absolute zin, hoog is (Schaap, 2014; 2018; Van Sluis \& Van de Walle, 2015; Van der Veer e.a., 2013). De bevindingen zijn veelal gebaseerd op gegevens van de European Social Survey, de International Self-Report Delinquency Study (ISRD-3) en de (Integrale) Veiligheidsmonitor (uitgevoerd door het Centraal Bureau voor de Statistiek).

De conclusies ten aanzien van de manier waarop het vertrouwen al dan niet versterkt kan worden, lopen uiteen. Van der Veer en collega's (2013) stelden dat het vertrouwen in de politie meer door het effectief optreden wordt verklaard dan door de procedureel rechtvaardige bejegening of legitimiteitsovertuigingen. De auteurs relativeerden de mate waarin inspanningen van de politie zouden kunnen leiden tot het vergroten van vertrouwen in de politie: 'het vertrouwen van burgers is maar zeer beperkt maakbaar door de politie' (p. 101). Broekhuizen en collega's (2015) vonden daarentegen dat er wel aanknopingspunten liggen voor de politie om het vertrouwen in de politie te versterken. In tegenstelling tot Van der Veer en collega's (2013) lieten ze zien dat het politiewerk sterker beïnvloed wordt door responsiviteit (de politie neemt je serieus) dan effectiviteit (de politie biedt bescherming). De auteurs benadrukten dat de politie meer zou kunnen investeren in de principes van procedurele rechtvaardigheid, omdat die essentieel zijn om negatieve ervaringen te voorkomen. In lijn met de conclusie van Broekhuizen en collega's (2015) vonden Van Sluis en Van de Walle (2015) dat burgers die positie- 
ver waren over de procedureel rechtvaardige bejegening door de politie ook meer vertrouwen in de politie hadden. Recentelijk kwam Schaap (2018) tot soortgelijke conclusies in zijn proefschrift. Procedurele rechtvaardigheid in ontmoetingen met de politie was sterk gecorreleerd met het vertrouwen in de politie. Verder veronderstelde Schaap dat het vertrouwen van burgers in autoriteiten, zoals de politie, leidt tot een grotere bereidheid om samen te werken.

Nederlands onderzoek naar de invloed van procedurele rechtvaardigheid op uitkomstmaten als de bereidheid tot samenwerken of delictgedrag is schaars (Van Kapel e.a., 2019; Koster, 2018). In een proefschrift over slachtoffers van criminaliteit liet Koster (2018) zien dat percepties van procedurele rechtvaardigheid en de effectiviteit van de politie niet van elkaar te onderscheiden zijn, met als gevolg dat beide concepten samengevoegd zijn tot een schaal. De gecombineerde schaal van procedurele rechtvaardigheid en effectiviteit had een direct verband met de samenwerking met de politie. Ook was er sprake van een indirect verband tussen beide concepten, dit verliep via legitimiteitsovertuigingen (de verplichting om te gehoorzamen). Van Kapel en collega's (2019) toonden een samenhang tussen de ervaren procedurele rechtvaardigheid, legitimiteitsovertuigingen en criminaliteit onder jongeren. Naarmate jongeren zich procedureel rechtvaardiger bejegend voelden door de politie, hadden ze hogere legitimiteitsovertuigingen. Ook pleegden jongeren minder criminaliteit wanneer ze de bejegening door de politie als meer procedureel rechtvaardig ervaren. Tot op heden is het verband tussen procedurele rechtvaardigheid en de samenwerking met actoren in de strafrechtketen echter nog niet getoetst onder de algemene bevolking in Nederland.

\section{Huidige studie}

Het doel van deze studie is om de hypothesen die zijn afgeleid van de procedurele rechtvaardigheidstheorie te toetsen in de Nederlandse context. Op basis van deze theorie (Tyler, 2003; 2006) is te verwachten dat mensen die zich procedureel rechtvaardiger bejegend voelen door de politie meer bereid zullen zijn om met actoren in de strafrechtketen samen te werken (hypothese 1 ). Daarnaast is te verwachten dat mensen die zich procedureel rechtvaardiger bejegend voelen door de politie ook hogere legitimiteitsovertuigingen hebben over de politie (hypothese 2). Tot slot valt te verwachten dat een procedureel rechtvaardige bejegening indirect samenhangt met de bereidheid om samen te werken met actoren in de strafrechtketen, via legitimiteitsovertuigingen (hypothese 3 ).

Vorenstaande hypothesen zijn tot op heden niet eerder empirisch onderzocht onder de algemene bevolking in Nederland, waardoor onbekend is in hoeverre in Nederland een procedureel rechtvaardige bejegening door de politie samenhangt met de bereidheid tot samenwerking met strafrechtactoren en met hoe men de legitimiteit van de politie ervaart. De bereidwilligheid van burgers om actoren in de strafrechtketen, zoals de politie, te helpen is van groot belang voor de preventie en het terugdringen van criminaliteit. Daarom is meer kennis over factoren die deze bereidwilligheid kunnen beïnvloeden van groot belang. 


\section{Methoden}

\section{Onderzoeksgroep}

De huidige studie maakte gebruik van een representatieve landelijke steekproef van Nederlanders die hebben deelgenomen aan de vijfde ronde (in 2010) van de European Social Survey (ESS). De ESS had een cross-sectioneel karakter en betrof een internationale vragenlijst die in meer dan 30 landen onder de bevolking afgenomen is. De ESS had tot doel om de veranderende publieke attitudes en waarden binnen Europa te volgen en te onderzoeken. Daarom is de vragenlijst herhaaldelijk afgenomen in meerdere rondes. In iedere ronde was er aandacht voor een nieuw thema. In de vijfde ronde is er specifiek aandacht besteed aan het vertrouwen in de politie en rechtbanken (Jackson e.a., 2011b). De huidige studie heeft gebruikgemaakt van de vragen die gesteld zijn over dit onderwerp. Alle vragen zijn gesteld in het Nederlands. Het onderzoek is uitgevoerd door middel van persoonlijke interviews (CAPI; computer-assisted personal interviewing) die ongeveer één uur in beslag namen. Enkel personen van 15 jaar of ouder die in particuliere huishoudens wonen, zijn ondervraagd, ongeacht nationaliteit, taal of (vreemdelingen)status.

Tussen september 2010 en januari 2011 hebben er in totaal 1.829 respondenten deelgenomen aan de ESS (ronde vijf) in Nederland (responspercentage is 60 procent). De steekproef was gestratificeerd en bestond uit twee stappen. Eerst zijn huishoudens geselecteerd op basis van een bestand van adressen in Nederland, vervolgens is er op basis van toeval bepaald welke personen in deze huishoudens geselecteerd werden (Norwegian Social Science Data Services, 2012). Om ervoor te zorgen dat de onderzoeksgroep vergelijkbaar is aan de populatie in Nederland zijn de analyses uitgevoerd met de voorgeschreven wegingsprocedure. ${ }^{2} \mathrm{Na}$ het verwijderen van respondenten die een of meerdere missende waarden hadden op de afhankelijke en/of de onafhankelijke variabelen bestond de onderzoeksgroep uit 1.616 respondenten.

\section{Variabelen}

\section{- Bereidheid om samen te werken met actoren in de strafrechtketen}

De afhankelijke variabele heeft betrekking op de bereidheid om met strafrechtactoren samen te werken. Respondenten konden aangeven op een vierpuntschaal in hoeverre ze bereid denken te zijn om 'de politie te bellen als er een man op straat omver wordt geduwd en wordt bestolen van zijn portemonnee', 'om een dader te identificeren' en 'om te getuigen in de rechtbank tegen de verdachte'. De scores op de drie items varieerden van 1 (helemaal niet waarschijnlijk/bereid) tot 4 (erg waarschijnlijk/bereid). Om de schaal te construeren, is de gemiddelde score van de drie items berekend (gemiddelde=3,34; $S D=, 59$; zie tabel 1). Een hogere score

2 European Social Survey (2014), zie www.europeansocialsurvey.org/docs/methodology/ESS_ weighting_data_1.pdf. 
weerspiegelde een hogere bereidheid om samen te werken met strafrechtactoren. De hoogte van de interne consistentie was redelijk (Cronbach's alpha $=, 72){ }^{3}$

\section{- Procedurele rechtvaardigheid}

De onafhankelijke variabele - procedurele rechtvaardigheid - is met behulp van drie items gemeten. Deze items weerspiegelden opvattingen, gebaseerd op wat respondenten hadden gehoord of zelf hadden meegemaakt, over hoe de politie mensen behandelt ('De politie behandelt mensen met respect') en de kwaliteit van beslissingen ('De politie maakt eerlijke, onpartijdige beslissingen in zaken' en 'De politie legt haar beslissingen en daden uit wanneer daar om gevraagd wordt'). Deze items kwamen overeen met internationaal onderzoek (Gau, 2011; Henderson e.a., 2010; Jackson e.a., 2011a; Reisig e.a., 2007). Respondenten is gevraagd om op een vierpuntschaal aan te geven in welke mate ze zich helemaal niet vaak (score 1) of heel vaak (score 4) procedureel rechtvaardig bejegend voelden door de politie. Bij het construeren van de schaal voor procedurele rechtvaardigheid is de gemiddelde score van de drie items berekend (gemiddelde=2,80; $S D=, 44$; zie tabel 1). ${ }^{4}$ De items zijn zo gecodeerd, dat een hogere score een positievere ervaren bejegening weerspiegelde. Er was sprake van een redelijke interne consistentie (Cronbach's alpha=,65).

\section{- Legitimiteit van de politie}

In de ESS zijn opvattingen over legitimiteit op twee manieren geoperationaliseerd, namelijk met een gedragsmatige dimensie (gehoorzaamheid aan de politie) en een morele dimensie (morele verbondenheid met de politie) (Jackson e.a., 2011b). De operationalisering als twee dimensioneel construct is in lijn met eerdere studies naar de effecten van legitimiteit (Jackson e.a., 2012; Tyler \& Jackson, 2014; Van Damme \& Pauwels, 2013). De ervaren verplichting om de politie te gehoorzamen is gemeten met drie items, waaronder 'Het is mijn plicht om achter besluiten van de politie te staan, zelfs als ik het er niet mee eens ben.' De morele verbondenheid met de politie is ook gemeten met drie items, zoals 'De politie heeft over het algemeen hetzelfde gevoel als ik over wat goed en fout is.' Aan de respondenten is gevraagd om op een vijfpuntschaal aan te geven in welke mate ze het eens of oneens zijn met de stellingen. De scores varieerden van 1 (helemaal niet mee eens) tot 5 (helemaal mee eens). Opnieuw is om de schalen (verplichting om de politie te gehoorzamen en de morele verbondenheid) te construeren de gemiddelde score van de afzonderlijke items berekend. Een hoge

3 De Cronbach's alpha is een maat voor interne consistentie van een set items. Alle items dienen hetzelfde construct te meten. Als er sprake is van interne consistentie, dan zijn de antwoorden van een respondent op verschillende items ongeveer hetzelfde. Een hogere Cronbach's alpha duidt op een hoge interne consistentie, andersom geeft een lage alpha een zwakke consistentie weer. Over het algemeen wordt een alpha van >,80 gezien als goed en <,60 als onvoldoende (De Heus e.a., 1995). In de praktijk worden Cronbach's alphas met een waarde van ,6 of hoger geaccepteerd (Pauwels, 2012).

4 Bij het vormen van de schalen voor de verplichting om de politie te gehoorzamen, de morele verbondenheid en de procedurele rechtvaardigheid moesten respondenten een geldige score hebben op minimaal twee van de drie items. 
score op deze schalen gaf een hogere ervaren legitimiteit van de politie weer, dus een sterkere verplichting om de politie te gehoorzamen (gemiddelde=3,27; $S D=$, 85; zie tabel 1) en een sterkere morele verbondenheid met de politie (gemiddelde=3,69; $S D=, 63$ ). De interne consistentie voor de schalen met betrekking tot de ervaren verplichting om de politie te gehoorzamen en de morele verbondenheid met de politie was redelijk (Cronbach's alpha=,79 en ,74, respectievelijk).

\section{Principale factoranalyse}

Met een principale factoranalyse is getoetst of de items van de onafhankelijke en afhankelijke variabelen op de verwachte constructen laadden (zie bijlage, tabel 5). De analyse liet duidelijke factoren zien. De items laadden op de verwachte constructen die de hiervoor beschreven concepten van procedurele rechtvaardigheid, morele verbondenheid, de verplichting om de politie te gehoorzamen en de samenwerking met strafrechtactoren representeerden. In de bijlage zijn de details van de principale factoranalyse uitgewerkt.

\section{Controlevariabelen}

Daarnaast zijn er zes controlevariabelen in de analyse toegevoegd. Er is gecontroleerd voor individuele kenmerken die een rol kunnen spelen bij de ontwikkeling van percepties van procedurele rechtvaardigheid en/of legitimiteitsovertuigingen en/of de bereidheid tot samenwerking. Deze variabelen zijn geselecteerd op basis van eerder onderzoek dat een samenhang tussen de controlevariabelen en de onafhankelijke en/of de afhankelijke variabelen heeft laten zien (Reisig e.a., 2007; 2012; Tyler \& Jackson, 2014; Van Damme \& Pauwels, 2013). De controlevariabelen zijn: geslacht, leeftijd, opleidingsniveau, migratieachtergrond, ervaren effectiviteit van de politie en persoonlijke moraliteit.

Geslacht was een dichotome variabele ( $0=$ man, $1=$ vrouw). De variabele leeftijd gaf de leeftijd van de respondent weer ( $15 \mathrm{t} / \mathrm{m} 95$ jaar). Het opleidingsniveau bestond uit drie categorieën: laag (basisschool tot vmbo), gemiddeld (havo tot mbo) en hoog (hbo tot doctoraat). Migratieachtergrond is als volgt bepaald: respondenten van wie beide ouders in Nederland zijn geboren (gecodeerd als 0 ) versus respondenten van wie een van beide (of beide) ouders buiten Nederland geboren is (gecodeerd als 1).

Naast voornoemde demografische achtergrondkenmerken zijn twee aanvullende controlevariabelen geïncludeerd. Ten eerste is de ervaren effectiviteit van de politie gemeten met de volgende twee items: 'Hoe succesvol is de politie in het voorkomen van misdrijven in Nederland?' en 'Hoe succesvol is de politie in het aanhouden van mensen die inbraken plegen in Nederland?' Respondenten konden op een vijfpuntschaal aangeven in hoeverre ze de politie niet succesvol (score van 1) of uiterst succesvol (score van 5 ) vonden. De schaal voor effectiviteit is vervolgens gemaakt door het gemiddelde van beide scores te berekenen. Een hogere score op de schaal effectiviteit betekent dat de respondent positiever is over de effectiviteit van de politie. Er was sprake van een redelijke interne consistentie (Cronbach's alpha=,72). Ten tweede is persoonlijke moraliteit gemeten aan de hand van drie items. Respondenten is gevraagd om aan te geven hoe verkeerd zij het vinden om 'een overdreven hoge of vervalste verzekeringsclaim in te die- 
Tabel 1 Achtergrondkenmerken van de onderzoeksgroep

\begin{tabular}{|c|c|c|c|c|c|c|}
\hline & $\mathbf{N}$ & $\%$ & $\begin{array}{l}\text { Mini- } \\
\text { mum }\end{array}$ & $\begin{array}{l}\text { Maxi- } \\
\text { mum }\end{array}$ & $\begin{array}{r}\text { Gemid- } \\
\text { delde }\end{array}$ & SD \\
\hline Samenwerking met strafrechtactoren & 1.616 & & $\mathrm{I}$ & 4 & 3,34 & ,59 \\
\hline $\begin{array}{l}\text { Verplichting om de politie te gehoor- } \\
\text { zamen }\end{array}$ & 1.616 & & 1 & 5 & 3,27 & ,84 \\
\hline Morele verbondenheid met de politie & 1.616 & & I & 5 & 3,69 & ,63 \\
\hline Procedurele rechtvaardigheid & 1.616 & & I & 4 & 2,80 & ,44 \\
\hline Leeftijd & 1.616 & & 15 & 95 & 46,04 & 17,43 \\
\hline Geslacht $(0=$ man $)$ & 1.616 & & 0 & I &, 50 &, 50 \\
\hline \multicolumn{7}{|l|}{ Opleidingsniveau } \\
\hline Laag & 538 & 33,3 & & & & \\
\hline Gemiddeld & 624 & 38,6 & & & & \\
\hline Hoog & 454 & 28,1 & & & & \\
\hline $\begin{array}{l}\text { Migratieachtergrond ( } 0=\text { beide ouders } \\
\text { in NL geboren) }\end{array}$ & 1.616 & & 0 & I &, 14 & ,35 \\
\hline Effectiviteit van de politie & 1.616 & & 1 & 5 & 2,50 & ,74 \\
\hline Persoonlijke moraliteit & 1.616 & & I & 4 & 3,19 & ,60 \\
\hline
\end{tabular}

nen', 'iets te kopen waarvan men dacht dat het gestolen was' en 'een verkeersovertreding te begaan'. De antwoordcategorieën varieerden van 1 (helemaal niet verkeerd) tot 4 (volkomen verkeerd). De schaal persoonlijke moraliteit is vervolgens geconstrueerd door de gemiddelde score van de drie items te berekenen. Een hogere score op deze schaal weerspiegelt dat respondenten sterkere intrinsieke morele principes hebben. De interne consistentie van deze schaal was redelijk (Cronbach's alpha $=, 70$ ).

In tabel 1 zijn de achtergrondkenmerken van de respondenten gepresenteerd. De helft van de groep bestond uit mannen. De respondenten hadden een gemiddelde leeftijd van 46 jaar. Ruim een derde van de respondenten had een gemiddeld opleidingsniveau (39 procent) en een derde had een laag opleidingsniveau (33 procent). Van de overgrote meerderheid van de respondenten (86 procent) waren beide ouders in Nederland geboren. Respondenten hadden gemiddeld genomen een neutraal oordeel over de effectiviteit van de politie. Over het algemeen hadden respondenten een hoge score op persoonlijke moraliteit.

\section{Analysebenadering}

Om een indruk te krijgen in hoeverre de procedureel rechtvaardige bejegening door de politie, legitimiteit en de bereidheid tot samenwerking met strafrechtactoren met elkaar samenhangen, is eerst de correlatiematrix bekeken.

Vervolgens is met behulp van de macro PROCESS in SPSS (Hayes, 2013) onderzocht in hoeverre een procedureel rechtvaardige bejegening door de politie, al dan niet via legitimiteitsovertuigingen, de bereidheid om samen te werken met straf- 
rechtactoren kan beïnvloeden. De macro is in feite een padmodel, dat de mogelijkheid biedt om meerdere multivariate regressieanalyses gelijktijdig uit te voeren, met als gevolg dat zowel de directe als de indirecte effecten die van belang zijn in het theoretisch model tegelijkertijd getoetst kunnen worden in één model..$^{5}$ Op deze manier was het dus mogelijk om het directe effect tussen procedurele rechtvaardigheidspercepties en de bereidheid tot samenwerking te toetsen, rekening houdend met het eventuele indirecte effect via legitimiteit. Bovendien was het mogelijk om het indirecte effect - de invloed van procedurele rechtvaardigheid via legitimiteit op de samenwerking - te toetsen, terwijl er rekening werd gehouden met het directe effect van procedurele rechtvaardigheid op de samenwerking. Dit is een voordeel ten opzichte van het uitvoeren van twee losse multivariate regressieanalyses omdat het interpreteren van twee aparte analyses geen informatie zou verschaffen over de significantie van een indirect effect (Hayes, 2009; Walters \& Mandracchia, 2017). Ondanks dat de resultaten in aparte tabellen (tabel 3 en 4; figuur 1) zijn gepresenteerd, zijn alle analyses in één model uitgevoerd.

Om de hypothesen te toetsen is nagegaan of percepties van procedurele rechtvaardigheid samenhangen met de bereidheid om samen te werken met strafrechtactoren (hypothese 1), of procedurele rechtvaardigheid samenhangt met de legitimiteitsovertuigingen over de politie (hypothese 2), en of het verband tussen procedurele rechtvaardigheid en de bereidheid om samen te werken met strafrechtactoren (gedeeltelijk) verklaard wordt door legitimiteitsovertuigingen (hypothese 3). In alle stappen zijn de controlevariabelen toegevoegd. Om de directe en indirecte effecten te toetsen, is model 4 uitgevoerd in de macro PROCESS. Dit model is specifiek ontworpen om een mediatie-effect te analyseren. Er werd gebruikgemaakt van bootstrapping, waarbij 5.000 samples gegenereerd zijn om betrouwbaarheidsintervallen te schatten voor de mediatie-effecten. ${ }^{6}$ Zonder deze intervallen was het niet mogelijk om de significantie van het mediatie-effect te bepalen. Het betrouwbaarheidsinterval (BI) is vastgesteld op 95 procent, dat betekent dat verbanden significant zijn bij een p-waarde kleiner dan .05 wanneer de linker en rechter grens van het betrouwbaarheidsinterval beide boven nul liggen óf beide onder nul liggen. Hoewel de macro relatief onbekend is binnen de criminologie, heeft eerder onderzoek de macro PROCESS aanbevolen (Walters \& Mandracchia, 2017), toegepast (Schroeder e.a., 2008; Söderberg e.a., 2016) én gebruikt in onderzoek naar de invloed van procedurele rechtvaardigheid op de samenwerking met de politie (Radburn e.a., 2018).

5 Een structureel vergelijkingsmodel (Structural Equation Modeling, SEM) zou ook een manier zijn om directe en indirecte effecten gelijktijdig in één model te toetsen.

6 Walters en Mandracchia (2017) beargumenteerden dat (en waarom) een bootstrappingtechniek te prefereren valt boven de toets van Baron en Kenny (1986) en de toets van Sobel (1982) bij het toetsen van een indirect effect. De precieze uitleg voert te ver voor dit artikel (zie p. 57 in de studie van Walters en Mandracchia). 
Tabel 2 Correlatiematrix van de concepten

\begin{tabular}{|c|c|c|c|c|c|}
\hline & Schalen & $\mathbf{I}$ & 2 & 3 & 4 \\
\hline I & Samenwerking met strafrechtactoren & 1 & & & \\
\hline 2 & Verplichting om te gehoorzamen &, $10^{* *}$ & 1 & & \\
\hline 3 & Morele verbondenheid &, $14^{* *}$ &, $23 * *$ & I & \\
\hline 4 & Procedurele rechtvaardigheid &, $14^{* *}$ &, $21 * *$ &, $47^{* *}$ & I \\
\hline
\end{tabular}

$\mathrm{N}=1.616$

$* p<.05 ; * * p<.01$

\section{Resultaten}

Tabel 2 toont de correlaties tussen de concepten. Er blijkt een statistisch significante correlatie tussen de procedureel rechtvaardige bejegening door de politie en de samenwerking met actoren in de strafrechtketen $(r=, 14, p<.01)$. Naarmate mensen vinden dat ze eerlijker en respectvoller bejegend worden door de politie, zijn ze bereidwilliger om met strafrechtactoren samen te werken. Daarnaast is er een statistisch significante correlatie tussen de procedureel rechtvaardige bejegening door de politie en de ervaren verplichting om de politie te gehoorzamen $(\mathrm{r}=, 21, \mathrm{p}<.01)$ en de morele verbondenheid met de politie $(\mathrm{r}=, 47, \mathrm{p}<.01)$. Dat wil zeggen dat naarmate men positiever is over de procedureel rechtvaardige bejegening door de politie, men de politie ook als meer legitiem beschouwt. Legitimiteitsovertuigingen, in de vorm van morele verbondenheid $(\mathrm{r}=, 14, \mathrm{p}<.01)$ en de ervaren verplichting om de politie te gehoorzamen $(r=, 10, p<.01)$, zijn ook gecorreleerd aan de bereidheid om met strafrechtactoren samen te werken. Kortom, de bivariate verbanden tussen de concepten lijken de hypothesen vooralsnog te ondersteunen.

\section{Procedurele rechtvaardigheid en de bereidheid om met strafrechtactoren samen te werken}

Allereerst is getoetst in hoeverre de procedureel rechtvaardige bejegening door de politie gerelateerd is aan de samenwerking met actoren in de strafrechtketen. Er blijkt een direct effect van procedurele rechtvaardigheidspercepties op de samenwerking met strafrechtactoren $(b=, 11, p<.01$; zie tabel 3$)$. De coëfficiënt kan worden gezien als een multivariate regressieanalyse waarin er geen rekening gehouden wordt met een indirect effect (zoals eerder beschreven onder het kopje 'Analysebenadering'). Bij het schatten van een indirect effect wordt er wel rekening gehouden met een mogelijk mediërend effect van legitimiteitsovertuigingen. Het indirecte effect van de procedureel rechtvaardige bejegening op de bereidheid om samen te werken met de politie is ook significant $(b=, 04$, $\mathrm{BI}=, 0054-, 0746)$. Hoewel zowel het directe als het indirecte effect (de ongestandaardiseerde b-coëfficiënten) statistisch significant is, is de omvang van het effect van een procedureel rechtvaardige bejegening door de politie relatief klein. Desalniettemin blijkt dat mensen die zich procedureel rechtvaardig bejegend voelen 
Tabel 3 Procedurele rechtvaardigheid, legitimiteitsovertuigingen en de bereidheid tot samenwerking met strafrechtactoren

\begin{tabular}{|c|c|c|c|}
\hline \multirow[t]{2}{*}{ Variabelen } & \multicolumn{3}{|c|}{ Bereidheid tot samenwerking } \\
\hline & b & SE & $\mathbf{t}$ \\
\hline Procedurele rechtvaardigheid (direct) ${ }^{\mathrm{a}}$ & , II &, 04 & $2,76 * *$ \\
\hline \multicolumn{4}{|l|}{ Mediatie-effect } \\
\hline Verplichting om te gehoorzamen ${ }^{\mathrm{b}}$ & ,03 & ,02 & 1,62 \\
\hline Morele verbondenheidc & ,05 & ,03 & $\mathrm{I}, 79$ \\
\hline \multicolumn{4}{|l|}{ Controlevariabelen } \\
\hline Geslacht (ref.=man) &,- 11 & ,03 & $-3,66 * * *$ \\
\hline Leeftijd &,- 00 &, 00 & $-3,51 * *$ \\
\hline \multicolumn{4}{|l|}{ Opleidingsniveau (ref.=laag) } \\
\hline Midden & , II & ,04 & $2,77 * *$ \\
\hline Hoog & , II & ,04 & $3,15^{* *}$ \\
\hline Migratieachtergrond (ref.=Nederlands) &,- 04 &, 04 & 0,93 \\
\hline Effectiviteit &,- 04 & ,02 & $-1,96$ \\
\hline Persoonlijke moraliteit & 09 &, 03 & 3,38 *** \\
\hline Constante & 2,85 &, 15 & $19,60 * * *$ \\
\hline F-toets & $7,4 I^{* * *}$ & & \\
\hline $\mathrm{R}^{2}$ & ,05 & & \\
\hline
\end{tabular}

${ }^{a}$ Het indirecte effect van procedurele rechtvaardigheid, rekening houdend met de mogelijkheid dat het verband via legitimiteit loopt, is ,04* $(\mathrm{BI}=, 0054-, 0746)$.

${ }^{b}$ Het indirecte effect van de verplichting om te gehoorzamen, rekening houdend met de mogelijkheid van een direct effect, is ,03 ( $\mathrm{BI}=-, 0029-, 0234)$.

' Het indirecte effect van morele verbondenheid, rekening houdend met de mogelijkheid van een direct effect, is ,03 (BI=-,004I-,0633).

$\mathrm{N}=1.616 ; \mathrm{b}=$ ongestandaardiseerde coëfficiënt; $\mathrm{SE}=$ standaard fout; $\mathrm{t}=\mathrm{t}$-ratio $* \mathrm{p}<.05 ; * * \mathrm{p}<.01 ; * * * \mathrm{p}<.001$

door de politie gemiddeld genomen bereidwilliger zijn om met strafrechtactoren samen te werken.

Verder zijn er enkele controlevariabelen statistisch significant gerelateerd aan de bereidheid om samen te werken met actoren in de strafrechtketen (zie tabel 3). Vrouwen zijn minder bereid om samen te werken met strafrechtactoren dan mannen $(b=-, 11, p<.001)$. Mensen met een hogere leeftijd zijn minder bereid om samen te werken dan mensen met een jongere leeftijd ( $b=-, 00, p<.001)$. Ten opzichte van mensen met een laag opleidingsniveau zijn mensen met een gemiddeld $(b=, 11, p<.01)$ of hoog $(b=, 11, p<.01)$ opleidingsniveau gemiddeld genomen meer bereid om samen te werken met strafrechtactoren. Tot slot, mensen met sterkere intrinsieke morele principes (persoonlijke moraliteit) zijn eerder geneigd om met strafrechtactoren samen te werken $(b=, 09, \mathrm{p}<.001)$. 


\section{Het verband tussen procedurele rechtvaardigheid en legitimiteit}

Vervolgens is het verband tussen de procedureel rechtvaardige bejegening door de politie en de legitimiteit van de politie onderzocht. Tabel 4 toont de resultaten van de analyse met de twee vormen van legitimiteit als uitkomstvariabelen. De procedureel rechtvaardige bejegening door de politie hangt significant samen met de ervaren verplichting om de politie te gehoorzamen $(b=, 33, p<.001)$ en de morele verbondenheid met de politie $(b=, 57, p<.001)$. Anders gezegd, naarmate mensen zich procedureel rechtvaardiger bejegend voelen door de politie, voelen ze zich over het algemeen meer verplicht om te gehoorzamen aan de aanwijzingen van de politie en voelen ze zich meer verbonden met de politie. Het model voor de ervaren verplichting om de politie te gehoorzamen verklaarde ongeveer 7 procent van de totale variantie en het model voor de morele verbondenheid met de politie verklaarde ongeveer 29 procent van de variantie.

Daarnaast blijken enkele controlevariabelen samen te hangen met legitimiteit (zie tabel 4). Zo voelen vrouwen zich minder verplicht om de politie te gehoorzamen dan mannen $(b=-, 22, p<.001)$. Mensen die vinden dat de politie effectief haar werk doet $(b=, 11, p<.001)$ en sterke intrinsieke morele principes hebben $(b=, 10$, $\mathrm{p}<.01)$, zijn eerder geneigd zich verplicht te voelen om te gehoorzamen aan de aanwijzingen van de politie. Ten aanzien van de morele verbondenheid met de politie blijken mensen met een hoger opleidingsniveau zich meer verbonden te voelen met de politie dan mensen met een laag opleidingsniveau ( $b=, 06, p<.05)$. Mensen met een migratieachtergrond ervaren in mindere mate een morele verbondenheid met de politie dan mensen zonder migratieachtergrond $(b=-, 13$, $\mathrm{p}<.001)$. Mensen die vinden dat de politie effectief haar werk doet, voelen zich meer verbonden met de politie $(b=, 19, \mathrm{p}<.001)$.

Procedurele rechtvaardigheid, legitimiteitsovertuigingen en de bereidheid om samen te werken

Tot slot is nagegaan of het verband tussen de procedureel rechtvaardige bejegening door de politie en de bereidheid om met actoren in de strafrechtketen samen te werken (deels) verklaard wordt door legitimiteitsovertuigingen. Met andere woorden, is er een samenhang tussen legitimiteitsovertuigingen over de politie en de bereidheid om samen te werken met strafrechtactoren, rekening houdend met het directe 'effect' van de procedureel rechtvaardige bejegening en de controlevariabelen? Tabel 3 toont de resultaten met betrekking tot de twee subschalen van legitimiteit en de bereidheid om samen te werken met strafrechtactoren. Zowel de ervaren verplichting om de politie te gehoorzamen als de morele verbondenheid met de politie hangt niet samen met de bereidheid tot samenwerking met strafrechtactoren $(b=, 03, p=.11 ; b=, 05, p=.07$, respectievelijk). Dit model verklaarde 5 procent van de variantie.

De afwezigheid van een samenhang tussen legitimiteit en de samenwerking met strafrechtactoren betekent dus dat er geen sprake is van een mediatie-effect. De samenhang tussen de procedureel rechtvaardige bejegening en de bereidheid tot samenwerking met strafrechtactoren wordt niet verklaard door legitimiteitsovertuigingen. Er is dus geen significant indirect effect dat via de ervaren verplichting 
Tabel $4 \quad$ Procedurele rechtvaardigheid en legitimiteitsovertuigingen

\begin{tabular}{|c|c|c|c|c|c|c|}
\hline \multirow[t]{2}{*}{ Variabelen } & \multicolumn{3}{|c|}{$\begin{array}{c}\text { Verplichting om te gehoor- } \\
\text { zamen }\end{array}$} & \multicolumn{3}{|c|}{ Morele verbondenheid } \\
\hline & b & SE & $\mathbf{t}$ & b & SE & $\mathbf{t}$ \\
\hline $\begin{array}{l}\text { Procedurele rechtvaardig- } \\
\text { heid }\end{array}$ & ,33 & 05 & $6,76^{* * * *}$ & ,57 & ,03 & $18,45^{* * * *}$ \\
\hline \multicolumn{7}{|l|}{ Controlevariabelen } \\
\hline Geslacht (ref.=man) &,- 22 & ,04 & $-5,35 * * *$ &,- 05 & ,03 & $-1,88$ \\
\hline Leeftijd &,- 00 &, 00 &,- 53 &, 00 &, 00 & $5,79 * * *$ \\
\hline \multicolumn{7}{|l|}{ Opleidingsniveau (ref.=laag) } \\
\hline Midden &,- 02 & ,05 &,- 40 & ,0l & ,03 &, 18 \\
\hline Hoog & ,01 & 05 &, 12 & ,06 & ,03 & $2,06 *$ \\
\hline $\begin{array}{l}\text { Migratie achtergrond } \\
\text { (ref.=Nederlands) }\end{array}$ &,- 02 & 06 &,- 28 &,- 13 & ,04 & $-3,35 * * *$ \\
\hline Effectiviteit & , II & ,03 & $3,91 * * *$ & 19 & ,02 & $10,59 * * *$ \\
\hline Persoonlijke moraliteit &, 10 & ,03 & $2,97^{* *}$ &, 02 & ,02 & 98 \\
\hline Constante & 2,12 & , 19 & $11,30 * * *$ & $\mathrm{I}, 37$ &, 12 & $11,32^{* * *}$ \\
\hline F-toets & $14,18^{* * * *}$ & & & $80,65 * * *$ & & \\
\hline $\mathrm{R}^{2}$ &, 07 & & &, 29 & & \\
\hline
\end{tabular}

$\mathrm{N}=1.616$; $b=$ ongestandaardiseerde coëfficiënt; $\mathrm{SE}=$ standaard fout; $\mathrm{t}=\mathrm{t}$-ratio $* \mathrm{p}<.05 ; * * \mathrm{p}<.01 ; * * * \mathrm{p}<.001$

om de politie te gehoorzamen ( $b=, 01, \mathrm{BI}=-, 0029-, 0234)$ of morele verbondenheid ( $b=, 03, \mathrm{BI}=-, 0041-, 0633$ ) loopt (zie voetnoten onder tabel 3). Wanneer de analyses uitgevoerd worden zonder de controlevariabelen (niet weergegeven in tabel 3), wordt er wel een significant mediatie-effect gevonden voor de ervaren verplichting om de politie te gehoorzamen $(b=, 02, B I=, 0006-, 0305)$. Dit betekent dat het verband tussen de procedureel rechtvaardige bejegening en de bereidheid tot samenwerking met strafrechtactoren gedeeltelijk wordt gemedieerd door de verplichting om de politie te gehoorzamen, wanneer er geen rekening wordt gehouden met de controlevariabelen.

Samenvattend staan in figuur 1 de belangrijkste resultaten, gebaseerd op tabel 3 en 4 , weergegeven. De resultaten laten zien dat de procedureel rechtvaardige bejegening samenhangt met de bereidheid om met actoren in de strafrechtketen samen te werken. Wanneer men zich procedureel rechtvaardiger bejegend voelt door de politie, is men eerder geneigd om samen te werken met strafrechtactoren (directe effect). Dit verband blijft statistisch significant na het toevoegen van de mogelijkheid dat het effect van procedurele rechtvaardigheidspercepties via legitimiteitsovertuigingen kan lopen (indirecte effect). De relatie tussen procedurele rechtvaardigheid en de samenwerking met strafrechtactoren wordt echter niet (gedeeltelijk) verklaard door de ervaren verplichting om aan de aanwijzingen van de politie te gehoorzamen of door de morele verbondenheid met de politie. Zoals in figuur 1 te zien, is er geen verband tussen de ervaren verplichting om de politie 


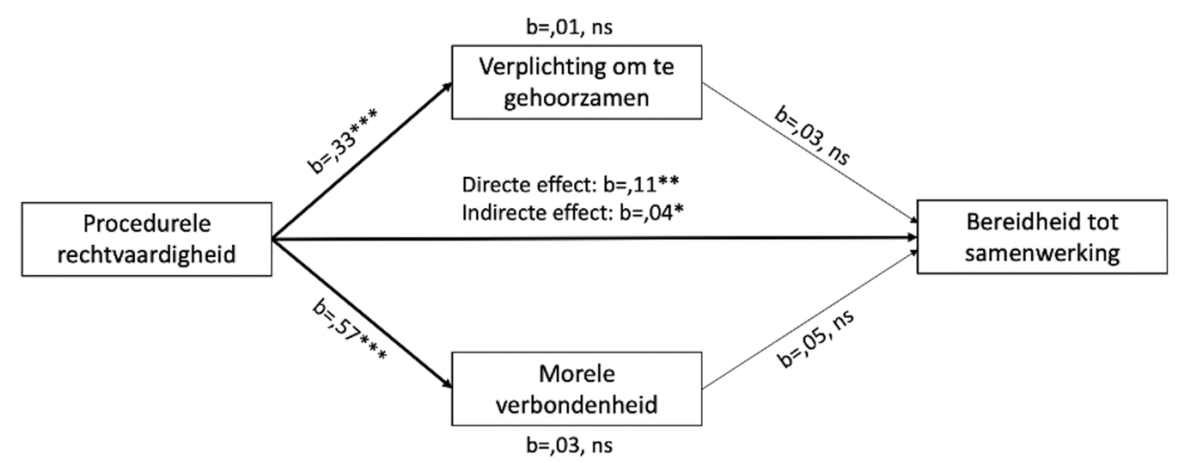

De $\mathrm{b}$ is de ongestandaardiseerde coëfficiënt, zoals gepresenteerd in tabel 3 en 4 .

${ }^{*} \mathrm{p}<.05 ;{ }^{* *} \mathrm{p}<.01 ;{ }^{* * *} \mathrm{p}<.001$

\section{Figuur 1 Schematisch overzicht van het theoretisch model (PROCESS-analyse)}

te gehoorzamen (of de morele verbondenheid met de politie) en de bereidheid tot samenwerking met strafrechtactoren.

\section{Discussie}

In de laatste decennia is er in toenemende mate aandacht voor het belang van procedurele rechtvaardigheid bij het begrijpen van houdingen van burgers ten opzichte van de wet en actoren in de strafrechtketen, zoals de politie. Deze interesse is vooral geïnspireerd door het werk van Tom Tyler en zijn collega's, die de determinanten en consequenties van procedurele rechtvaardigheid hebben onderzocht (Sunshine \& Tyler, 2003; Tyler, 2006; Tyler \& Fagan, 2008; Tyler \& Huo, 2002). Tot op heden is het echter onduidelijk in hoeverre de uitgangspunten van de procedurele rechtvaardigheidstheorie gelden in Nederland, omdat onderzoek onder de algemene bevolking naar de mate waarin procedurele rechtvaardigheid gerelateerd is aan de samenwerking met actoren in de strafrechtketen simpelweg ontbreekt. Daarom is het doel van deze studie om te onderzoeken of, en in hoeverre, de procedureel rechtvaardige bejegening door de politie samenhangt met de bereidheid om samen te werken met strafrechtactoren, en welke rol de legitimiteit van de politie in deze relatie speelt.

De huidige studie heeft laten zien dat percepties van procedurele rechtvaardigheid inderdaad gerelateerd zijn aan de bereidheid om met actoren in de strafrechtketen samen te werken. Deze bereidheid houdt in dat burgers voornemens zijn om de politie te alarmeren bij het constateren van een strafbaar feit, of dat ze bereid zijn tot het getuigen tegen een verdachte in de rechtbank. Het blijkt dat mensen die procedures als eerlijker ervaren en zich respectvoller bejegend voelen door de politie, ook bereidwilliger zijn om samen te werken. Dit onderzoek vindt geen ondersteuning voor een mediatie-effect. Dat wil zeggen dat de relatie tussen de procedureel rechtvaardige bejegening en de bereidheid tot samenwerking met 
strafrechtactoren niet gemedieerd wordt door legitimiteitsovertuigingen. Hoewel de procedureel rechtvaardige bejegening wel samenhangt met legitimiteit (zowel met de ervaren verplichting om de politie te gehoorzamen als met de morele verbondenheid met de politie), hangen deze legitimiteitsovertuigingen niet samen met de bereidheid tot samenwerking met strafrechtactoren. De analyses zonder controlevariabelen laten wel een mediërend effect zien van de ervaren verplichting om de politie te gehoorzamen.

De bevinding dat mensen eerder bereid zijn om samen te werken met actoren in de strafrechtketen wanneer ze zich eerlijker en respectvoller bejegend voelen door de politie, ondersteunt de eerste hypothese. Dit is in lijn met de procedurele rechtvaardigheidstheorie (Tyler, 2006) en sluit aan bij bestaand onderzoek dat ook heeft laten zien dat wanneer mensen positiever zijn over de procedureel rechtvaardige bejegening door de politie, zij ook eerder geneigd zijn om met strafrechtactoren, zoals de politie, samen te werken (Bolger \& Walters, 2019; Kochel, 2018; Radburn e.a., 2018; Reisig \& Lloyd, 2009; Sun e.a., 2017). Deze bevinding komt ook overeen met een studie onder slachtoffers van criminaliteit in Nederland, die eveneens liet zien dat percepties van procedurele rechtvaardigheid samenhangen met de bereidheid tot samenwerking (Koster, 2018).

Het waargenomen effect van de procedureel rechtvaardige bejegening door de politie op de bereidheid om samen te werken met actoren in de strafrechtketen is echter bescheiden. Er zijn verschillende verklaringen mogelijk voor dit bescheiden effect. Ten eerste is het huidige onderzoek uitgevoerd in Nederland. In vergelijking met andere landen hebben Nederlanders over het algemeen een gemiddelde tot hoge score op procedurele rechtvaardigheid (Jackson e.a., 2011a; 2013). In het huidige onderzoek bleek ook dat mensen gemiddeld genomen redelijk positieve scores hebben met betrekking tot de procedureel rechtvaardige bejegening door de politie, en de variantie bleek laag. Meer variantie in hoe de bejegening door de politie ervaren wordt, zou mogelijk tot een groter effect geleid kunnen hebben. Ten tweede heeft bestaand onderzoek laten zien dat percepties van procedurele rechtvaardigheid tijdens specifieke ontmoetingen met de politie een minder sterke invloed hebben op legitimiteitsovertuigingen dan algemene (en bredere) opvattingen over de procedurele rechtvaardigheid van de politie (Gau, 2014). Ten derde is er in deze studie rekening gehouden met persoonlijke moraliteit. Mensen met sterke intrinsieke morele principes zijn eerder bereid om met strafrechtactoren samen te werken dan mensen met minder sterke intrinsieke morele principes, zo blijkt uit de resultaten. Hoewel deze bevinding logisch lijkt, hebben slechts enkele studies de invloed van persoonlijke moraliteit getoetst in een model met procedurele rechtvaardigheid (Hough e.a., 2010; Jackson e.a., 2015; Reisig e.a., 2014; Van Damme \& Pauwels, 2013). Gegeven de theoretische link tussen persoonlijke moraliteit en procedurele rechtvaardigheid (Tyler, 2006), is het aannemelijk dat persoonlijke moraliteit het effect van procedurele rechtvaardigheid beperkt.

De bevindingen met betrekking tot de mediërende rol van legitimiteit zijn slechts gedeeltelijk in overeenstemming met Tylers (2006) procedurele rechtvaardigheidstheorie. In de huidige studie is wel een samenhang tussen percepties van procedurele rechtvaardigheid en legitimiteitsovertuigingen gevonden. Deze 
bevinding is in lijn met de theorie en ondersteunt de tweede hypothese. Ook vele andere studies hebben deze samenhang tussen procedurele rechtvaardigheid en legitimiteit aangetoond, zowel in Nederland (Van Kapel e.a., 2019; Koster, 2018) als buiten Nederland (Bolger \& Walters, 2019; Reisig \& Lloyd, 2009; Reisig e.a., 2012; Tyler \& Jackson, 2014; Van Damme \& Pauwels, 2013). In tegenstelling tot de derde hypothese, werd er geen ondersteuning gevonden dat legitimiteitsovertuigingen samenhangen met de samenwerking met actoren in de strafrechtketen. Mensen die de politie als legitiemer erkennen, zijn niet eerder bereid om met strafrechtactoren, zoals de politie, samen te werken. Dit betekent tegelijkertijd dat er geen mediatie-effect van legitimiteit gevonden is. Het verband tussen procedurele rechtvaardigheid en de bereidheid tot samenwerking met strafrechtactoren wordt niet (gedeeltelijk) verklaard door legitimiteit. ${ }^{7}$ Het merendeel van de eerdere studies heeft echter wel een verband gevonden tussen legitimiteit van de politie en de bereidheid tot samenwerken met strafrechtactoren (Bolger \& Walters, 2019; Reisig e.a., 2012; Tyler \& Jackson, 2014; Van Damme \& Pauwels, 2013; Woo e.a., 2018). Een mogelijke verklaring kan zijn dat de huidige studie de onderlinge relaties, waaronder het mediatie-effect van legitimiteit, in één analysemodel heeft getoetst. Dit wijkt deels af van bestaand onderzoek, dat afzonderlijke multivariate regressieanalyses gebruikt en geïnterpreteerd heeft (zie bijvoorbeeld Murphy e.a., 2008; Reisig \& Lloyd, 2009; Reisig e.a., 2012; Sun e.a., 2017; Tyler \& Fagan, 2008; Tyler \& Jackson, 2014). Hierbij moet opgemerkt worden dat er in toenemende mate gebruik is - en wordt - gemaakt van structurele vergelijkingsmodellen ('Structural Equation Modeling'), zie bijvoorbeeld de artikelen van Jackson en Bradford (2009) en Jackson en collega's (2012; 2015).

De huidige studie is niet zonder beperkingen. De eerste beperking heeft betrekking op de uitkomstvariabele. Deze variabele is gebaseerd op de verwachte bereidheid van respondenten om samen te werken met actoren in de strafrechtketen. Er is dus geen gebruik gemaakt van gegevens die het feitelijk gedrag van mensen hebben gemeten. Daarnaast is de bereidheid tot samenwerking breed geformuleerd en kan de constructvaliditeit bekritiseerd worden. Toekomstig onderzoek zou moeten overwegen om items toe te voegen over het feitelijk gedrag en over de mate waarin burgers geneigd zijn om samen te werken in andere situaties (denk aan het bellen van de politie wanneer in een huis of auto wordt ingebroken, het verrichten van een burgerarrestatie, het verstrekken van informatie over een verdachte van een strafbaar feit tijdens een opsporingsonderzoek, of het alarmeren van de politie bij een verdachte situatie in de buurt).

De tweede beperking betreft de cross-sectionele onderzoeksopzet. Hierdoor is het niet mogelijk om conclusies te trekken over de causaliteit van de gevonden relaties. Toekomstig longitudinaal onderzoek waarbij mensen over de tijd herhaaldelijk bevraagd worden naar de procedureel rechtvaardige bejegening door de

7 De afwezigheid van een verband tussen legitimiteit en de bereidheid om samen te werken moet worden bezien in de context van deze studie, namelijk het directe contact tussen de burger en de politie. Legitimiteit zou mogelijk wel een rol kunnen spelen als het gaat om situaties waarin de politie meer in het algemeen de hulp van burgers inschakelt om bijvoorbeeld verdachte situaties te melden. 
politie, hun opvattingen over legitimiteit en hun bereidheid om met strafrechtactoren samen te werken, is nodig om de causaliteit van de verbanden te toetsen.

De derde beperking betreft het feit dat het model met betrekking tot de samenwerking met actoren in de strafrechtketen relatief weinig variantie verklaarde (5 procent, zie tabel 3). Deze bevinding suggereert dat mogelijk andere theoretisch relevante variabelen belangrijk zijn bij het voorspellen van de bereidheid tot samenwerking met strafrechtactoren, zoals de sociale identiteit van respondenten (Bradford, 2014; Radburn e.a., 2018).

De vierde beperking heeft betrekking op de validiteit van de onafhankelijke variabelen procedurele rechtvaardigheid en effectiviteit. Hoewel de gehanteerde items voor deze variabelen een indicatie geven van de concepten, zou toekomstig onderzoek moeten nadenken over een meer valide meting van procedurele rechtvaardigheid (bijvoorbeeld door het includeren van items als 'de politie was beleefd tegen mij', 'de politie behandelde mij rechtvaardig' of 'de politie gaf mij de kans om een mening te geven voordat de beslissing werd genomen') en effectiviteit (bijvoorbeeld door het opnemen van items als 'de politie pakt wapenbezit aan', 'de politie pakt drugscriminaliteit aan' of 'de politie is in staat om orde te handhaven op straat').

De vijfde beperking betreft de periode waarin de vragenlijsten zijn afgenomen bij Nederlanders. De resultaten weerspiegelen de situatie van ongeveer tien jaar terug. Het is goed mogelijk dat respondenten andere scores zouden invullen wanneer ze recent opnieuw bevraagd zouden worden over de bejegening door de politie, de bereidheid tot samenwerking en/of legitimiteitsovertuigingen, wat zou resulteren in andere uitkomsten. Desondanks lijkt er geen aanleiding te zijn om de resultaten in de huidige studie als achterhaald te beschouwen, mede omdat de gegevens afkomstig zijn uit een landelijke representatieve steekproef. Echter, om te toetsen of de gevonden resultaten daadwerkelijk nog actueel zijn, moet er toekomstig (longitudinaal) onderzoek uitgevoerd worden.

Ondanks de beperkingen draagt de huidige studie bij aan de literatuur over procedurele rechtvaardigheid in Nederland, vanwege de focus op de procedureel rechtvaardige bejegening door de politie, legitimiteitsovertuigingen over de politie en bereidheid tot samenwerking onder de algemene bevolking. Daarnaast is het belangrijk om potentiële beïnvloedbare determinanten voor de bereidheid om samen te werken met strafrechtactoren empirisch te onderzoeken. Bovendien heeft de huidige studie de hypothesen getoetst met een analyse waarin alle theoretische verwachtingen in één model zijn onderzocht.

Wat betekenen de bevindingen voor ontmoetingen tussen de politie en burgers? Politieagenten kunnen zelden beslissingen nemen waarover alle betrokken partijen tevreden zijn, dit speelt vooral in situaties van persoonlijke geschillen. Politieagenten die burgers toestaan hun bezorgdheid of boosheid te uiten en burgers respectvol bejegenen, vergroten de kans dat burgers positiever zijn over de ervaren procedurele rechtvaardigheid, onafhankelijk van de uiteindelijke uitkomst. Vervolgens zullen burgers die vinden dat politieagenten hen op een procedureel rechtvaardige wijze bejegenen, eerder bereid zijn om met de actoren in de strafrechtketen, waaronder de politie, samen te werken. De politie heeft er dus belang bij dat ze aandacht besteedt aan de manier waarop ze burgers bejegent 
en de wijze waarop ze beslissingen neemt. Gezien de waarde van een procedureel rechtvaardige bejegening, zou de politie kunnen overwegen om in trainingen en opleidingsprogramma's meer aandacht te besteden aan de betekenis en het belang van procedurele rechtvaardigheid in hun ontmoetingen met burgers (voor onderzoek naar effecten van dergelijke trainingen, zie bijvoorbeeld Skogan e.a., 2015; Wood e.a., 2020).

Tot slot, de huidige studie biedt belangrijke inzichten in de manier waarop de procedureel rechtvaardige bejegening door de politie samenhangt met houdingen ten opzichte van de politie. De resultaten suggereren dat politieagenten kunnen bijdragen aan het vergroten van de legitimiteit van de politie en de bereidheid van burgers om samen te werken met strafrechtactoren door hen in ontmoetingen op een eerlijke en respectvolle manier te behandelen. Dit is belangrijk, omdat de bereidwilligheid van burgers om strafrechtactoren, zoals de politie, te helpen van groot maatschappelijk belang is voor de preventie en het terugdringen van criminaliteit.

\section{Literatuur}

Baron, R.M. \& Kenny, D.A. (1986). The moderator-mediator variable distinction in social psychological research: conceptual, strategic, and statistical considerations. Journal of Personality and Social Psychology, 51(6), 1173-1182.

Blader, S.L. \& Tyler, T.R. (2009). Testing and extending the group engagement model: linkages between social identity, procedural justice, economic outcomes, and extra-role behavior. Journal of Applied Psychology, 94(2), 445-464.

Bolger, P.C. \& Walters, G.D. (2019). The relationship between police procedural justice, police legitimacy, and people's willingness to cooperate with law enforcement: a metaanalysis. Journal of Criminal Justice, 60, 93-99.

Bradford, B. (2014). Policing and social identity: procedural justice, inclusion and cooperation between police and public. Policing and Society, 24(1), 22-43.

Broekhuizen, J., Kapel, M. van, Steketee, M. \& Roetman, L. (2018). Vertrouwen in een rechtvaardige behandeling door de politie. Utrecht: Verwey-Jonker Instituut.

Broekhuizen, J., Stokkum, B. van, Schaap, D., Maier, D., Boutellier, H. \& Boers, J. (2015). Serieus nemen: over het vertrouwen van burgers in de Amsterdamse politie. Amsterdam: Vrije Universiteit.

Damme, A. van \& Pauwels, L. (2013). Naleving van de wet en medewerking van burgers met politie: (alleen) een kwestie van procedurele rechtvaardigheid? Panopticon, 34(3), 182-203.

Damme, A. van, Pauwels, L. \& Svensson, R. (2015). Why do Swedes cooperate with the police? A SEM analysis of Tyler's procedural justice model. European Journal on Criminal Policy and Research, 21(5), 15-33.

Dijk, J. van. (2007). 100\%. Een onderzoek naar het vertrouwen van burgers in de politie. Den Haag: Ministerie van Binnenlandse Zaken en Koninkrijksrelaties.

Gau, J.M. (2011). The convergent and discriminant validity of procedural justice and police legitimacy: an empirical test of core theoretical propositions. Journal of Criminal Justice, 39(6), 489-498.

Gau, J.M. (2014). Procedural justice and police legitimacy: a test of measurement and structure. American Journal of Criminal Justice, 39(2), 187-205. 
Goodman-Delahunty, J. (2010). Four ingredients: new recipes for procedural justice in Australian policing. Policing: A Journal of Policy and Practice, 4(4), 403-410.

Hayes, A.F. (2009). Beyond Baron and Kenny: statistical mediation analysis in the new millennium. Communication Monographs, 76(4), 408-420.

Hayes, A.F. (2013). An Introduction to Mediation, Moderation, and Conditional Process Analysis: A Regression-Based Approach. New York: Guilford Press.

Henderson, H., Wells, W., Maguire, E.R. \& Gray, J. (2010). Evaluating the measurement properties of procedural justice in a correctional setting. Criminal Justice and Behavior, 37(4), 384-399.

Heus, P. de, Leeden, R. van der \& Gazendam, B. (1995). Toegepaste data-analyse. Technieken voor niet-experimenteel onderzoek in de sociale wetenschappen. Utrecht: Uitgeverij Lemma.

Hough, M., Jackson, J., Bradford, B., Myhill, A. \& Quinton, P. (2010). Procedural justice, trust, and institutional legitimacy. Policing: A Journal of Policy and Practice, 4(3), 203-210.

Jackson, J. \& Bradford, B. (2009). Crime, policing and social order: on the expressive nature of public confidence in policing. The British Journal of Sociology, 60(3), 493-521.

Jackson, J., Hough, M., Bradford, B. \& Kuha, J. (2015). Empirical legitimacy as two connected psychological states. In: G. Meško \& J. Tankebe (eds.). Trust and Legitimacy in Criminal Justice: European Perspectives in Europe. New York: Springer, 137-160.

Jackson, J., Bradford, B., Hough, M., Myhill, A., Quinton, P. \& Tyler, T.R. (2012). Why do people comply with the law? Legitimacy and the influence of legal institutions. British Journal of Criminology, 52(6), 1051-1071.

Jackson, J., Hough, M., Bradford, B., Pooler, T., Hohl, K. \& Kuha, J. (2011a). Trust in Justice: Topline Results from Round 5. Brussels: European Commission.

Jackson, J., Kuha, J., Hough, M., Bradford, B., Hohl, K. \& Gerber, M. (2013). Trust and Legitimacy across Europe: A FIDUCIA Report on Comparative Public Attitudes towards Legal Authority. Retrieved from http://eprints.lse.ac.uk/50650/.

Jackson, J., Bradford, B., Hough, M., Kuha, J., Stares, S.R., Widdop, S., Fitzgerald, R., Yordanova, M. \& Galev, T. (2011b). Developing European indicators of trust in justice. European Journal of Criminology, 8(4), 267-285.

Kapel, M. van, Broekhuizen, J. \& Steketee, M. (2019). Vertrouwen van jongeren in een rechtvaardige behandeling door de politie. Ervaren procedurele rechtvaardigheid, legitimiteit van de politie en zelfgerapporteerde criminaliteit onderzocht op basis van de ISRD-3. In: J. Noppe, A. Verhage, K. van der Vijver \& E. Kolthoff (red.). Politie en legitimiteit. Cahiers Politiestudies. Oud-Turnhout: Gompel\&Svacina, 73-98.

Karakus, O. (2017). Instrumental and normative pathways to legitimacy and public cooperation with the police in Turkey: considering perceived neighborhood characteristics and local government performance. Justice Quarterly, 34(1), 25-54.

Kochel, T. (2018). Police legitimacy and resident cooperation in crime hotspots: effects of victimisation risk and collective efficacy. Policing and Society, 28(3), 251-270.

Koster, N.N. (2018). Crime victims and the police: Crime victims' evaluations of police behaviour, legitimacy, and cooperation: a multi-method study. $\mathrm{PhD}$ thesis Universiteit Leiden.

MacCoun, R.J. (1993). Drugs and the law: a psychological analysis of drug prohibition. Psychological Bulletin, 113(3), 497-512.

MacQueen, S. \& Bradford, B. (2015). Enhancing public trust and police legitimacy during road traffic encounters: results from a randomized controlled trial in Scotland. Journal of Experimental Criminology, 11(3), 419-443. 
Mazerolle, L., Antrobus, E., Bennett, S. \& Tyler, T.R. (2013). Shaping citizen perceptions of police legitimacy: a randomized field trial of procedural justice. Criminology, 51(1), 33-63.

Murphy, K., Hinds, L. \& Fleming, J. (2008). Encouraging public cooperation and support for police. Policing and Society, 18(2), 136-155.

Nagin, D.S. (1998). Criminal deterrence research at the outset of the twenty-first century. In: M. Tonry (ed.). Crime and Justice: An Annual Review of Research. Chicago: University of Chicago Press, 1-42.

Norwegian Social Science Data Services. (2012). ESS5 - 2010 Documentation Report: The ESS Data Archive. Edition 2.1. Retrieved from www.europeansocialsurvey.org/docs/ round5/survey/ESS5_data_documentation_report_e04_2.pdf.

Os, P.G. van, Brink, G. van den \& Baardewijk, J. (2007). Heterdaad-kracht. Aanhoudend in de buurt. Apeldoorn: Politieacademie.

Pauwels, L. (2012). Toegepaste statistiek met SPSS voor criminologen. Antwerpen: Maklu.

Piquero, A.R., Fagan, J., Mulvey, E.P., Steinberg, L. \& Odgers, C. (2005). Developmental trajectories of legal socialization among serious adolescent offenders. Journal of Criminal Law \& Criminology, 96(1), 267-298.

Radburn, M., Clifford, S., Bradford, B. \& Robinson, M. (2018). When is policing fair? Groups, identity and judgements of the procedural justice of coercive crowd policing. Policing \& Society, 28(6), 647-664.

Regioplan. (2005). Actieve wederkerigheid. De beïnvloedbaarheid van oordelen over het contact met en de beschikbaarheid van de politie. Amsterdam: Intomart GfK/Regioplan.

Reisig, M.D. (2007). Procedural justice and community policing: what shapes residents' willingness to participate in crime prevention programs? Policing: A Journal of Policy \& Practice, 1(3), 356-368.

Reisig, M.D. \& Chandek, M. (2001). The effect of expectancy disconfirmation on outcome satisfaction in police-citizen encounters. Policing: An International Journal of Police Strategies and Management, 24(1), 88-99.

Reisig, M.D. \& Lloyd, C. (2009). Procedural justice, police legitimacy, and helping the police fight crime. Police Quarterly, 12(1), 42-62.

Reisig, M.D., Bratton, J. \& Gertz, M.G. (2007). The construct validity and refinement of process-based policing measures. Criminal Justice and Behavior, 34(8), 1005-1028.

Reisig, M.D., Tankebe, J. \& Meško, G. (2012). Procedural justice, police legitimacy, and public cooperation with the police among young Slovene adults. Journal of Criminal Justice \& Security, 14(2), 147-164.

Reisig, M.D., Tankebe, J. \& Meško, G. (2014). Compliance with the law in Slovenia: the role of procedural justice and police legitimacy. European Journal on Criminal Policy and Research, 20, 259-276.

Sampson, R.J. \& Bartusch, D.J. (1998). Legal cynicism and (subcultural?) tolerance of deviance: the neighborhood context of racial differences. Law \& Society Review, 32(4), 777-804.

Sampson, R.J., Raudenbush, S.W. \& Earls, F. (1997). Neighborhoods and violent crime: a multilevel study of collective efficacy. Science, 277(5328), 918-924.

Schaap, D. (2014). Ontwikkelingen in het vertrouwen van burgers in de politie in Nederland en Europa. Tijdschrift voor de Politie, 76(1), 28-31.

Schaap, D. (2018). The police, the public, and the pursuit of trust. Den Haag: Eleven International Publishing.

Schaap, D., \& Scheepers, P. (2014). Comparing citizens' trust in the police across different countries: an assessment of cross-country measure equivalence. International Criminal Justice Review, 24(1), 82-98. 
Schroeder, R.D., Giordano, P.C. \& Cernkovich, S.A. (2008). Drug use and desistance processes. Criminology, 45(1), 191-222.

Skogan, W. \& Frydl, K. (2004). Fairness and Effectiveness in Policing: The Evidence. Washington: The National Academies Press.

Skogan, W., Craen, M. van \& Hennessy, C. (2015). Training police for procedural justice. Journal of Experimental Criminology, 11(3), 319-334.

Sluis, A. van \& Walle, S. van de (2015). The significance of police-citizen contacts for public trust in the police in the Netherlands. European Journal of Policing Studies, 3(1), 78-98.

Smith, D.J. (2007). The foundations of legitimacy. In: T.R. Tyler (ed.). Legitimacy and Criminal Justice: An International Perspective. New York: Russell Sage, 30-58.

Sobel, M. (1982). Asymptotic confidence intervals for indirect effects in structural equation models. Sociological Methods, 13, 290-312.

Söderberg, P., Bjorkqvist, K. \& Österman, K. (2016). Exploring the effects of physical punishment on aggressive behavior and peer victimization: a conditional process analysis. Journal of Aggression, Conflict and Peace Research, 8(1), 21-32.

Sun, I.Y., Wu, Y., Hu, R. \& Farmer, A.K. (2017). Procedural justice, legitimacy, and public cooperation with police: does Western wisdom hold in China? Journal of Research in Crime and Delinquency, 54(4), 454-478.

Sunshine, J. \& Tyler, T.R. (2003). The role of procedural justice and legitimacy in shaping public support for policing. Law \& Society Review, 37(3), 513-548.

Tankebe, J. (2009). Public cooperation with the police in Ghana: does procedural fairness matter? Criminology, 47(4), 1265-1293.

Terpstra, J. (2008). Burgers over de politie. Over de betekenis en relevantie van burgeropvattingen. In: C.D. van der Vijver \& P. Deelman (red.). De verantwoordelijkheid voor veiligheid. Dordrecht: SMVP, 31-50.

Thibaut, J.W. \& Walker, L. (1975). Procedural Justice: A Psychological Analysis. Hillsdale: Erlbaum.

Tsushima, M. \& Hamai, K. (2015). Public cooperation with the police in Japan: testing the legitimacy model. Journal of Contemporary Criminal Justice, 31(2), 212-228.

Tyler, T.R. (2001). Public trust and confidence in legal authorities. What do majority and minority group members want from the law and legal institutions? Behavioral Sciences \& the Law, 19(2), 215-235.

Tyler, T.R. (2003). Procedural justice, legitimacy, and the effective rule of law. In: M. Tonry (Ed.). Crime and Justice: A Review of Research. Chicago: University of Chicago Press, 431-505.

Tyler, T.R. (2006). Why People Obey the Law. Princeton: Princeton University Press.

Tyler, T.R. (2009). Legitimacy and criminal justice: the benefits of self-regulation. Ohio State Journal of Criminal Law, 7(1), 307-360.

Tyler, T.R. \& Fagan, J. (2008). Legitimacy and cooperation: why do people help the police fight crime in their communities? Ohio State Journal of Criminal Law, 6(1), 231-275.

Tyler, T.R. \& Huo, Y.J. (2002). Trust in the Law: Encouraging Public Cooperation with the Police and Courts. New York: Russell Sage Foundation.

Tyler, T.R. \& Jackson, J. (2014). Popular legitimacy and the exercise of legal authority: motivating compliance, cooperation and engagement. Psychology, Public Policy and Law, 20(1), 78-95.

Tyler, T.R. \& Murphy, K. (2011). Procedural Justice, Police Legitimacy and Cooperation with the Police: A New Paradigm for Policing. Brisbane: ARC Centre of Excellence in Policing and Security.

Tyler, T.R. \& Wakslak, C.J. (2004). Profiling and police legitimacy: procedural justice, attributions of motive, and acceptance of police authority. Criminology, 42(2), 253-282. 
Veer, L. van der, Sluis, A. van, Walle, S van de \& Ringeling, A. (2013). Vertrouwen in de politie: trends en verklaringen. Apeldoorn: Politie \& Wetenschap.

Walters, G.D. \& Mandracchia, J.T. (2017). Testing criminological theory through causal mediation analysis: current status and future directions. Journal of Criminal Justice, 49, 53-64.

Woo, Y., Maguire, E.R. \& Gau, J.M. (2018). Direct and indirect effects of procedural justice on cooperation and compliance: evidence from South Korea. Police Practice and Research, 19(2), 168-185.

Wood, G., Tyler, T.R. \& Papachristos, A.V. (2020). Procedural justice training reduces police use of force and complaints against officers. Proceedings of the National Academy of Sciences of the United States of America (PNAS), 117(18), 9815-9821.

Worden, R.E. \& McLean, S.J. (2017). Mirage of police reform. Procedural justice and police legitimacy. Oakland: University of California Press.

\section{Bijlage}

\section{Principale factoranalyse}

Om na te gaan of de items van de onafhankelijke en afhankelijke variabelen op de verwachte constructen laadden, werd er een principale factoranalyse uitgevoerd. Dit betreft een exploratieve factoranalyse, uitgevoerd in SPSS. Omdat de items op verschillende schalen gemeten werden (procedurele rechtvaardigheid op een vierpuntschaal, legitimiteit op een vijfpuntschaal), zijn alle items gestandaardiseerd voor de factoranalyse. De analyse is met een schuine rotatie (de zogeheten Promax-rotatie) uitgevoerd, omdat de constructen naar verwachting met elkaar correleren. De items bleken geschikt te zijn voor de principale factoranalyse (KaiserMeyer-Olkin test=,73; Bartlett's test of sphericity $\chi^{2}=4582,32, \mathrm{p}<.001$ ). Door het gebruik van een schuine rotatie zijn de patrooncoëfficiënten gepresenteerd.

De factoranalyse liet een duidelijk patroon zien (zie tabel 5). De items met betrekking tot procedurele rechtvaardigheid laadden op één construct; dat gold ook voor de items over morele verbondenheid, de ervaren verplichting om de politie te gehoorzamen en de samenwerking met strafrechtactoren. Er waren geen items die op twee of meer constructen tegelijk laadden of items die een te lage factorlading toonden. Kortom, de resultaten ondersteunen de discriminante validiteit van procedurele rechtvaardigheid ten opzichte van legitimiteit dat als morele verbondenheid met de politie en de ervaren verplichting om de politie te gehoorzamen gemeten was (Gau, 2011; 2014; Reisig e.a., 2007). 


\section{Tabel 5 Factoranalyse}

\begin{tabular}{lll}
\hline I & $\begin{array}{l}\text { Procedurele } \\
\text { rechtvaardig- }\end{array}$ & $\begin{array}{l}\text { De politie behandelt } \\
\text { mensen met respect. } \\
\text { heid }\end{array}$ \\
& $\begin{array}{l}\text { De politie makt eer- } \\
\text { lijke, onpartijdige } \\
\text { beslissingen in zaken. } \\
\text { De politie legt haar } \\
\text { beslissingen en daden } \\
\text { uit wanneer daar om } \\
\text { wordt gevraagd. }\end{array}$
\end{tabular}

$4 \quad$ Verplichting Het is mijn plicht om om de politie achter besluiten van te gehoorza- de politie te staan, men zelfs als ik het er niet mee eens ben.

Het is mijn plicht om te doen wat de politie zegt, zelfs als ik de reden niet begrijp of het er niet mee eens ben.

6

Het is mijn plicht om

$\begin{array}{rrrrr}\text { I } & \mathbf{2} & \mathbf{3} & \mathbf{4} & \mathbf{h}^{\mathbf{2}} \\ , 04 & , 02 & , 01 & , \mathbf{6 6} & , 46 \\ , 01 & -, 04 & -, 02 & , 65 & , 40 \\ & & & & , 28 \\ , 02 & , 04 & , 05 & , 48 & , 20\end{array}$
te doen wat de politie zegt, zelfs als ik de manier waarop niet prettig vind.

De politie heeft over bondenheid het algemeen hetzelfde

$\begin{array}{lllll}, 05 & -, 01 & 0 & , 63 & , 03\end{array}$
met de gevoel als ik over wat politie goed en fout is. waarden die belangrijk zijn voor mensen zoals ik.

Over het algemeen sta

, 02 ik achter de manier waarop de politie doorgaans optreedt. 
Tabel $5 \quad$ (Vervolg)

\begin{tabular}{|c|c|c|c|c|c|c|c|}
\hline & & & $I$ & 2 & 3 & 4 & $h^{2}$ \\
\hline 10 & $\begin{array}{l}\text { Samenwer- } \\
\text { king met } \\
\text { strafrechtac- } \\
\text { toren }\end{array}$ & $\begin{array}{l}\text { Hoe waarschijnlijk is } \\
\text { het dat u de politie } \\
\text { zou bellen als er een } \\
\text { man op straat omver } \\
\text { wordt geduwd en } \\
\text { wordt bestolen van } \\
\text { zijn portemonnee? }\end{array}$ & ,48 &,- 01 &,- 01 &, 15 & .26 \\
\hline 11 & & $\begin{array}{l}\text { Hoe bereidwillig bent } \\
\text { u om de dader te iden- } \\
\text { tificeren? }\end{array}$ & ,97 &,- 02 &, 00 &,- 07 & .92 \\
\hline \multirow[t]{3}{*}{12} & & $\begin{array}{l}\text { Hoe bereidwillig bent } \\
\text { u om te getuigen in de } \\
\text { rechtbank tegen de } \\
\text { verdachte? }\end{array}$ & ,67 & ,0I & ,02 &,- 01 & .45 \\
\hline & & Eigenwaarde & 3,2 & 1,9 & $\mathrm{I}, 7$ & $\mathrm{I}, 0$ & \\
\hline & & Variantie (\%) & 26,3 & 15,5 & 14,1 & 8,3 & \\
\hline
\end{tabular}

$\mathrm{N}=1.616$; schuine rotatie (Promax); patrooncoëfficiënten zijn gepresenteerd.

Kaiser-Meyer-Olkin ,73; Bartlett's test of sphericity 4582,32, $p<.001$. 